\title{
Upaya Guru Dalam Memaksimalkan Perkembangan Kognitif, Sosial dan Motorik Anak Usia Dini
}

\author{
Muhammad Khoiruzzadi', Mabid Barokah ${ }^{2}$, Aisiyatin Kamila ${ }^{3}$ \\ 1,2,3 UIN Sunan Kalijaga Yogyakarta
}

\begin{abstract}
DOI : https://doi.org/10.15642/jeced.v2i1.56

Abstract
The purpose of this study is to determine the efforts of teachers in developing
children's potential, and want to know the obstacles experienced by teachers
on cognitive, social and motor development. This research is included in the
field research. The approach used is a descriptive qualitative approach.
Primary data is data obtained from interviews with class B1 group teachers
and school principals, as well as the results of observations of learning both
inside and outside the class B1 group RA Ar-RahmahSleman Regency. The
results showed that teachers need to understand the ideal development of a
child in terms of cognitive, social and motor aspects. RA Ar-Rahmah group
B1 has different character and development. The learning done by teachers
in group B1 children is more varied in using learning methods such as
singing, habituation, exemplary, advice, and others in accordance with what
material is intended to be taught to children. In addition, excellent programs
also encourage teachers to think together so that the desired goals of the
school are achieved.
\end{abstract}

\begin{tabular}{l}
\hline Abstrak \\
Tujuan penelitian ini adalah untuk mengetahui upaya guru dalam \\
menumbuhkankembangkan potensi anak, dan ingin mengetahui hambatan \\
yang dialami guru pada perkembangan kognitif, sosial dan motorik. \\
Penelitian ini termasuk dalam penelitian lapangan. Pendekatan yang \\
digunakan adalah pendekatan kualitatif deskriptif. Data primer adalah data \\
yang diperoleh dari hasil wawancara dengan guru kelas kelompok B1 dan \\
kepala sekolah, serta hasil observasi pembelajaran baik di dalam maupun di \\
luar kelas kelompok B1 RA Ar-Rahmah Kabupaten Sleman. Hasil penelitian \\
menunjukkan bahwa guru perlu mengerti perkembangan ideal seorang anak \\
dilihat dari aspek kognitif, sosial dan motoriknya. RA Ar-Rahmah kelompok \\
B1 memiliki karakter dan perkembangan yang berbeda-beda. Pembelajaran \\
yang dilakukan guru pada anak kelompok B1 lebih bervariatif dalam \\
menggunakan metode belajarnya seperti bernyanyi, pembiasaan, \\
keteladanan, nasihat, dan lainnya sesuai dengan materi apa yang hendak \\
diajarkan kepada anak. Selain itu, program-program unggulan yang dimiliki \\
RA Ar-Rahmah juga mendorong guru untuk berpikir bersama agar tujuan \\
yang dikehendaki sekolah tercapai.
\end{tabular}

Article Info

Article history:

Received: 10042020

Accepted: 09062020

Published online: 15062020

Keywords:

teacher

cognitive

social

motoric

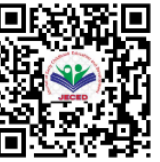

\section{InformasiArtikel \\ RiwayatArtikel}

Revisiterakhir: 10042020

Diterima: 09062020

Publikasi online: 15062020

\section{Kata kunci:}

guru

kognitif

sosial

motoric 


\section{PENDAHULUAN}

Anak usia dini merupakan seorang anak yang usianya belum memasuki suatu lembaga pendidikan formal seperti Sekolah dasar (SD) dan biasanya mereka tetap tinggal di rumah atau mengikuti kegiatan dalam bentuk berbagai lembaga pendidikan pra-sekolah, seperti kelompok bermain, taman kanak-kanak, atau taman penitipan anak (Nurmalitasari, 2015, h. 103). Hal lain yang tak kalah penting bahwasanya anak usia dini berada pada tahap perkembangan kritis atau emas (golden age). Perkembangan pada anak usia dini dapat dilakukan dengan berbagai pendekatan, baik pendekatan umur, pendekatan jangka hidup, pendekatan ekologi. Secara umum pendekatan umur merupakan pendekatan tradisional yang digunakan untuk melihat perkembangan pada anak. Sederhananya, perkembangan anak usia dini dapat diketahui dari usia, tingkah laku, dan kondisi fisik atau yang lainnya (Yus, 2015, h. 9).

Pada anak usia dini yang sudah memasuki usia 5-6 tahun, idealnya para orang tua menyekolahkan anaknya pada pendidikan formal yaitu Taman kanak-kanak. Harapan dari setiap orang tua adalah ingin melihat hasil belajar anaknya maksimal. Maka dari itu, para guru di sekolah perlu memperbaiki diri supaya pembelajaran di kelas maupun di luar kelas menghasilkan apa yang dicita-citakan bersama, seperti pengetahuan guru tentang pembelajaran seni tari yang dapat meningkatkan perkembangan motorik anak (Untariana dkk., 2019, h. 251), penggunaan pendekatan pembelajaran eksplorasi (Dewi dkk., 2019, h. 215), pembelajaran berbasis double loop problem solving(Suciasih dkk., 2019, h. 226), dan penggunaan media-media audio visual untuk memaksimalkan perkembangan kognitif anak (Putri, 2019, h. 246).

Tak kalah pentingnya mengenai perkembangan motorik anak usia dini yang perlu dilatih untuk menguatkan otot-otot anak. Perkembangan motorik pada anak usia dini bisa dibedakan menjadi dua yaitu motorik kasar dan motorik halus. Motorik kasar berkaitan dengan penggunaan otot-otot besar, dan kegiatannya dapat menguras energi seperti berlari, jalan-jalan, menari, dan sebagainya. Berbeda dengan motorik kasar, motorik halus hanya melibatkan otot kecil pada anak seperti kegiatan menyusun balok. Selain itu, untuk meningkatkan motorik halus pada anak juga bisa menggunakan metode proyek berbasis pendekatan saintifik (Mulandini dkk., 2019, h. 36).

Pada masa anak usia dini juga perlu diperhatikan perkembangan sosial anak. Baik di sekolah maupun di rumah, anak mulai dikenalkan dengan orang-orang baru di sekitarnya, diajarkan dan dicontohkan untuk berperilaku sopan santun, mengerti tata krama kepada orang yang lebih tua, dan hal lainnya yang berkaitan dengan aspek sosial anak. Anak juga perlu dipertontonkan filmfilm yang mengandung nilai akhlak (Astuti, 2013, h. 133). Ternyata untuk kasus beberapa anak yang mengalami masalah pada motoriknya juga akan berdampak pada aspek sosial dan emosional anak (Piek dkk., 2008, h. 143). Hal yang perlu dipahami bahwa proses perkembangan anak itu terjadi sesuai dengan pola yang sudah ada pada diri anak itu sendiri yang ditentukan oleh potensi genetik dan juga pengaruh faktor lingkungan sekitar (Venetsanou \& Kambas, 2010, h. 319).

Ketiga perkembangan tersebut baik kognitif, sosial dan motorik anak juga tergantung pada jenis kelaminnya. Anak laki-laki biasanya akan lebih aktif dibandingkan kebanyakan anak perempuan (Krombholz, 2006, h. 477). Di sinilah peran guru di sekolah dan orang tua di rumah untuk memaksimalkan perkembangan anak apalagi anak pada usia 4-6 tahun mudah dibentuk sesuai dengan didikan lingkungan sekitarnya. Seperti orang tua yang suka meminum-minuman keras juga dapat berdampak negatif pada perkembangan kognitif anak (Noll dkk., 1992, h. 665), sehingga gerak motorik anak juga akan bermasalah. Contoh lain adalah ketika anak sudah mengalami kecanduan terhadap gadget dan komputer juga kurang baik bagi anak, kecuali anak diajarkan penggunaan gadget dan komputer berbasis pendidikan dan diarahkan dengan baik akan meningkatkan kemampuan kognitif dan motorik anak (Li \& Atkins, 2004, h. 1715).

Taman kanak-kanak merupakan tempat belajar sekaligus bermain anak, jangan sampai anakanak pada usia dini tertekan dan stres karena beban pelajaran yang terlalu berat. Guru harus mengerti dan jeli pada setiap anak yang mengalami penurunan semangat dalam belajar dan 
bermain. Perkembangan kognitif pada anak TK menurut Piaget berada pada tahapan praoperasional yang memiliki ciri tersendiri dibandingkan dengan cara berpikir anak sebelum usia 2 tahun dan sesudah 7 tahun (Desmita, 2010, h. 76; Dwiyogo, 2018, h. 20; Hurlock, 2014, h. 34; Purna \& Kinasih, 2017, h. 19). Sama halnya dengan perkembangan sosial anak menurut Erickson yang mengembangkan teori kepribadian Sigmund Freud yang berkaitan dengan pemenuhan kebutuhan biologis (Hurlock, 2014, h. 117; Purna \& Kinasih, 2017, h. 29). Serta perkembangan motorik anak yang sewajarnya anak usia dini lakukan sesuai dengan usianya.

Di Indonesia, perbedaan antara Taman kanak-kanak (TK) dengan Raudhatul athfal (RA) hanya perbedaan pengelolaan lembaga saja. TK dikelola oleh Departemen Pendidikan Nasional sedangkan RA dikelola oleh Departemen Agama. RA setara dengan TK, di mana kurikulumnya ditekankan pada pemberian rangsangan pendidikan untuk membantu pertumbuhan dan perkembangan jasmani dan rohani agar anak memiliki kesiapan ke pendidikan selanjutnya (Darmadi, 2018, h. 20). Selain materi umum, RA memperkenalkan pula dasar-dasar ajaran agama Islam kepada anak didiknya (Muslih \& Rahimah, 2018, h. 37). RA Ar-Rahmah Kabupaten Sleman memiliki beberapa program unggulan yang sudah direncanakan bersama dengan guru, wali murid, dan perwakilan Kementerian Agama Kabupaten Sleman. Tujuannya tidak lain adalah mengembangkan potensi yang dimiliki anak sekaligus membekali anak dengan pengenalan ajaran agama Islam seperti mengenal huruf hijaiyah, berdoa, hafal surat pendek, nama-nama malaikat, dan masih banyak lagi.

Tujuan dari penelitian ini adalah untuk mengetahui upaya guru dalam menumbuhkankembangkan potensi anak, baik dari perkembangan kognitif, sosial dan motorik anak. Selain itu, juga ingin mengetahui hambatan yang dialami guru selama mengajar khususnya pada perkembangan kognitif, sosial dan motoriknya. Dan yang tak kalah penting adalah teori perkembangan anak dan teori belajar akan digunakan dalam menganalisis dari hasil penelitian yang sudah didapat.

\section{METODE}

Dalam penelitian ini termasuk dalam penelitian lapangan (field research). Pendekatan yang digunakan adalah pendekatan kualitatif deskriptif, yaitu prosedur penelitian yang menghasilkan data deskriptif berupa kata-kata tertulis atau lisan dari orang-orang dan perilaku yang dapat diamati, dengan sumber datanya yang terdiri dari data primer dan data sekunder. Untuk data primer adalah data yang diperoleh dari hasil wawancara dengan guru kelas kelompok B1 dan kepala sekolah, serta hasil observasi pembelajaran baik di dalam maupun di luar kelas kelompok B1 RA Ar-Rahmah Papringan Caturtunggal, Kecamatan Depok, Kabupaten Sleman. Sedangkan data sekunder diperoleh dari dokumentasi baik berupa teks maupun dokumen lain yang terkait dengan fokus penelitian di RA Ar-Rahmah Papringan Caturtunggal, Kecamatan Depok, Kabupaten Sleman.

Setelah data tersebut terkumpul, langkah selanjutnya adalah menganalasisnya. Langkah peneliti dalam menganalisis data tersebut dimulai dengan menelaah seluruh data yang telah terkumpul. Data tersebut tentunya sangat banyak, setelah dibaca dan dipelajari, maka langkah berikutnya adalah melibatkan tiga komponen analisis, yaitu: reduksi data, penyajian data, dan penarikan kesimpulan.

Tabel 1. Data Subjek Penelitian

\begin{tabular}{ccccc}
\hline No & Nama & Usia & JenisKelamin & Jabatan/Posisi \\
\hline 1 & AM & 44 & P & Kepalasekolah \\
2 & AR & 29 & P & Guru Kelas B1 \\
3 & HK & 6 & L & Siswa
\end{tabular}




\begin{tabular}{cccll}
4 & RAG & 6,5 & L & Siswa \\
5 & RIZ & 6 & L & Siswa \\
6 & SAF & 6 & P & Siswa \\
7 & AIN & 6,5 & P & Siswa \\
8 & FAU & 6 & L & Siswa \\
9 & SEP & 6 & L & Siswa \\
10 & YSF & 6 & L & Siswa \\
11 & FAD & 6,5 & L & Siswa \\
12 & ALK & 6 & P & Siswa \\
13 & AND & 6,5 & L & Siswa \\
14 & IRF & 6,5 & L & Siswa \\
15 & LST & 6 & P & Siswa \\
16 & LL & 6,5 & P & Siswa \\
\hline
\end{tabular}

\section{HASIL PENELITIAN DAN ANALISIS \\ Hasil Penelitian}

Berdasarkan hasil penelitian baik secara observasi maupun wawancara, setidaknya penulis membagi 3 tema yaitu tantangan guru dalam aspek perkembangan kognitif anak, aspek sosial anak, dan aspek motorik anak.

\section{Aspek Perkembangan Kognitif Anak}

Visi dari RA Ar-Rahmah adalah terwujudnya generasi penerus andalan yang cerdas, kreatif, aktif, dan taqwa kepada Allah Swt., kemudian dari visi ini melahirkan salah satu program unggulan dari RA Ar-Rahmah yaitu program tahfidz. Pengenalan-pengenalan dalam berhitung, abjad, mewarnai, menggambar, pendalaman materi dasar agama Islam seperti membaca sederhana tentang huruf hijaiyah, hafalan surat pendek, doa-doa sebelum berkegiatan, nama-nama malaikat dan tugasnya, rukun iman, rukun Islam, praktek wudhu, pengenalan dan praktek tentang bacaan salat dan gerakannya, dan bacaan-bacaan asmaul husna haruslah dipraktekan setiap harinya. Harapan dari kepala sekolah adalah semua anak yang sekolah di RA Ar-Rahmah adalah hafal juz 'amma, namun kendala masalah waktu dan hanya mengandalkan program dari sekolah saja, harapan tersebut cukup sulit untuk direalisasikan.

Pembelajaran dimulai dari jam 07.30-11.00 untuk kelompok B kecuali di hari Jum'at dan Sabtu hanya sampai pada jam 10.30. Dalam satu minggu hanya libur sekali di hari Minggu saja, dengan program yang bergantian setiap harinya diharapkan dapat mengurangi kejenuhan terhadap anak. Berikut adalah tabel kegiatan tambahan yang ada di RA Ar-Rahmah.

Tabel 2. Kegiatan Rutin dalam Satu Minggu

\begin{tabular}{lll}
\hline No & \multicolumn{1}{c}{ Hari } & \multicolumn{1}{c}{ Kegiatan } \\
\hline 1 & Senin & Upacara \\
2 & Selasa & Menonton film yang mendidik \\
3 & Rabu & Tidakada \\
4 & Kamis & Praktek wudhu dan salat \\
5 & Jumat & Olahraga \\
6 & Sabtu & Melukis dan tadabur alam \\
\hline
\end{tabular}




\section{HASIL DAN PEMBAHASAN}

Perkembangan kognitif anak di kelompok B beragam, ada anak ketika diajarkan pada pengenalan angka atau berhitung sederhana, anak langsung responsif dan cepat dalam menjawab, namun ada juga yang membutuhkan waktu dalam menjawabnya, begitupun pada pengenalan huruf sederhana. Kemampuan membaca untuk anak TK/RA tidak hanya terbatas pada pengertian membaca seperti biasa. Sebagaimana penuturan AM selaku kepala sekolah, "membaca gambar, membaca warna, dan lainnya itu adalah juga termasuk dalam kemampuan membaca." (Wawancara dengan Ibu Almunah pada tanggal 27 Februari 2020 jam 09.20).

Untuk mengembangkan aspek kognitif pada anak, para guru menggunakan pendekatan kontekstual kepada anak baik anak yang perkembangan kognitifnya cepat atau lambat. Salah satu hal yang penting dalam kegiatan belajar mengajar adalah terpenuhinya sarana dan prasarana dalam mengembangan aspek kognitif anak, selain itu diperlukan metode yang tepat dalam mengajarkan anak khususnya yang berkaitan dengan kognitif anak seperti berhitung, menghafal, menulis, menggambar, mewarnai dan membaca. Menurut AR selaku guru kelompok B, metode bernyanyi masih menjadi metode andalan dalam mengenalkan sesuatu yang baru khususnya pada aspek kognitif anak.

Baik menurut AM maupun AR, tidak ada pemaksaan dari guru ketika ada anak yang belum bisa berhitung, menghafal dan membaca dengan baik. Para guru menyadari betul bahwa kemampuan tiap anak berbeda-beda. Ada anak yang cepat dalam menghafal namun di sisi lain pada aspek sosialnya masih kurang. Inilah keunikan dari anak-anak pada fase pertumbuhan secara fisik dan perkembangan secara mental. Dari 14 siswa ada beberapa anak yang menonjol seperti subjek IRF. IRF sangat menonjol pada membaca dan hitung menghitung seperti perkalian dan pembagian, yang mana di sekolah tidak diajarkan tentang perkalian dan pembagian. Menurut AM selaku kepala sekolah, "IRF memang lebih mudah untuk diajari. Kemudian ketika diberi soal perhitungan sederhana malah meminta soal yang lebih sulit." (Wawancara dengan Ibu Almunah pada tanggal 27 Februari 2020 jam 09.20).

Penilaian guru dalam menilai aspek kognitif anak adalah dengan melihat perkembangan dalam menulis, menghafal, menggambar, membaca, dan menghitung. Jika ada anak yang belum mampu secara sempurna namun setidaknya ada perkembangan mesikpun sedikit, anak dinilai layak untuk melanjutkan ke jenjang pendidikan selanjutnya. Karena di RA Ar-Rahmah tidak mengenal istilah tinggal kelas, kecuali jika ada yang belum cukup umur, kepala sekolah akan memberikan arahan dan masukan kepada wali murid untuk setahun lagi duduk di bangku RA. Bukan tanpa alasan dalam memberikan masukan kepada wali murid, kepala sekolah melihat anak akan kesulitan ketika dipaksakan masuk ke jenjang SD. Namun pada akhirnya, semuanya diserahkan pada wali murid, apakah mau mengikuti arahan dan masukan dari kepala sekolah dan guru atau tetap memaksa anaknya naik ke jenjang SD.

Hambatan dalam mengembangkan aspek kognitif anak, sebagaimana penuturan dari guru kelompok B1 (AR),

"Hambatan yang sulit itu adalah dari anak itu sendiri, saya sebagai guru memaklumi akan hal itu. Kemudian kami para guru akan memberikan stimulasi atau rangsangan yang dapat membangkitkan motivasi anak serta penerapan metode yang tepat dalam mengembangan otak anak. Hal lainnya adalah kadang ada beberapa wali murid yang menyerahkan sepenuhnya kepada sekolah, padahal untuk memaksimalkan potensi anak perlu adanya kerjasama yang baik antara guru di sekolah, dan orang tua di rumah." (Wawancara dengan Ibu Asih Rodhiyah pada tanggal 26 Februari 2020 jam 11.10).

\section{Aspek Sosial Anak}

Selain pintar secara kognitif, anak juga harus bisa menerima dan diterima di lingkungan sekitarnya. Kemampuan sosial pada anak juga perlu dikembangkan dari sedini mungkin supaya anak tidak minder, pemalu, mau bergaul dengan temannya, mau berkomunikasi dengan temannya. 
Berdasarkan hasil observasi selama jam istirahat, anak di kelompok B1 mau bermain bersama. Saling memberi juga nampak dari beberapa anak. Tidak ada perbatasan dalam berteman, anak lakilaki bebas bermain dan berkomunikasi dengan anak perempuan.

Cara guru dalam mengoptimalkan aspek sosial anak adalah dengan melihat kondisi perkembangan sosial anak. Sebagaimana penuturan dari AR selaku guru kelas, "Guru mengajarkan aspek sosial kepada anak itu tergantung anaknya mas. Ada memang anaknya yang sudah berani maju, percaya diri, berani ngobrol dengan temannya. Nah biasanya di kelas B itu sudah tidak terlalu masalah untuk sosialisasinya mas karena mereka sudah mengenal guru dan temannya satu tahun lebih." (Wawancara dengan Ibu Asih Rodhiyah pada tanggal 26 Februari 2020 jam 11.15).

Hal senada juga diiyakan oleh AM selaku kepala sekolah, "Awalnya kami para guru itu mengajarkan bersalam-salaman baik sesama teman, kepada guru, kemudian bermain kelompok, mengajarkan anak maju ke depan, diajarkan untuk saling menolong, menghormati orang yang lebih tua, memutarkan film dengan tema pertemanan dan saling tolong menolong, dan masih banyak lagi." (Wawancara dengan Ibu Almunah pada tanggal 27 Februari 2020 jam 09.30)

Hambatan-hambatan dalam pengembangan aspek sosial anak adalah ketika anak diajarkan dengan baik di sekolah, namun ketika anak di rumah, orang tua tidak memberikan penguatanpenguatan yang sudah anak ajarkan di sekolah. Selain itu, anak yang perlu pendekatan lebih karena anak kurang berani untuk bersosial, para guru akan memberikan rangsangan-rangsangan agar anak berani untuk bersosialisasi. Rangsangan-rangsangan yang dimaksud adalah dengan menyuruh anak maju, memimpin barisan, memimpin doa, dan yang lainnya.

\section{Aspek Motorik Anak}

Taman kanak-kanak merupakan tempat untuk bermain sekaligus belajar untuk anak. Di TK/RA, anak akan diberikan rangsangan dan stimulus untuk menguatkan otot-otot anak dan menumbuhkankembangkan pertumbuhan fisiknya. Salah satu hal yang bertugas adalah pada aspek motorik anak. RA Ar-Rahmah memiliki program harian, mingguan, dan tahunan untuk mengoptimalkan aspek motorik anak. Aspek inilah yang akan membuat anak semakin lincah, gesit, dan bersemangat setiap harinya.

Guru kelompok B1 dalam mengembangkan aspek motorik anak adalah dengan membaginya kedalam dua kegiatan yang dapat menunjang perkembangan motorik halus anak dan motorik kasar anak. Pada aspek motorik halus anak, guru mengajarkan anak menyusun balok, menganyam, menempel, mainan puzzle, menggambar, mewarnai, membuat baris, menebalkan baris, dan masih banyak lagi. Sedangkan kegiatan yang dapat menunjang aspek motorik kasar anak adalah dengan membebaskan anak bermain seperti bermain ayunan, perosotan, jungkit-jungkit dan yang lainnya sesuai dengan kemampuan sarana prasana di sekolah. Kemudian program mingguan seperti senam dan olahraga di hari Jumat dan jalan sehat di hari Sabtu merupakan upaya dari sekolah untuk mengembangkan aspek motorik kasar pada anak. Program tahunan adalah mengadakan kegiatan outbond di luar lingkungan sekolah.

Guru sebagai tonggak keberhasilan dalam memaksimalkan perkembangan motorik anak di sekolah, perlu mengawasi anak dan menasehati anak ketika bermain di halaman sekolah. Selain itu, guru juga memberikan penjelasan kepada anak terkait bahaya apa saja jika bermain dengan alat permainan di sekolah. Dan guru selalu mengingatkan kepada anak untuk selalu berhati-hati dalam bermain selama beristirahat.

Hambatan yang dialami para guru untuk memaksimalkan perkembangan motorik anak sebagaimana penjelasan dari AR, "Ketika ada anak yang berkelahi, atau terjatuh dari permainan sehingga anak akan menjadi trauma dalam bermain permainan tersebut. Biasanya orang tua akan memarahi kepada anak untuk tidak bermain permainan tersebut." (Wawancara dengan Ibu Asih Rodhiyah pada tanggal 26 Februari 2020 jam 11.15). Hal ini malah akan membuat anak semakin takut, dan akan mengurangi gerak motorik kasar sehingga anak lebih suka berdiam di kelas. 


\section{PEMBAHASAN}

Dari beberapa hasil penelitian di atas, penulis akan membahasnya dengan membagi kembali ke dalam 2 tema yaitu pengulangan dan variasi belajar, dan kemampuan ideal anak sesuai perkembangannya. Dalam pembahasan ini menggunakan beberapa teori yaitu teori belajar, teori psikologi perkembangan dan teori pendidikan.

\section{Pembiasaan dan variasi belajar}

Dalam prakteknya RA Ar-Rahmah menggunakan banyak pendekatan dan metode dalam mengajarkan anak khususnya pada aspek perkembangan kognitif anak. Penggunaan metode pembiasaan dilakukan dengan mengajak anak untuk melakukan dan membiasakan kegiatan yang bernilai-nilai positif khsususnya di sekolah sehingga mampu diterapkan di rumah dan masyarakat (Fakhruddin, 2019, h. 373). Selain itu metode pembiasaan digunakan agar anak tidak cepat lupa dan diusahakan untuk membiasakan apa yang diajarkan oleh guru kepada anak seperti diajarkan anak untuk mandiri (Iswantiningtyas \& Raharjo, 2016, h. 62; Khoiruzzadi \& Fajriyah, 2019, h. 142; Silranti \& Yaswinda, 2019, h. 39). Pavlov menjelaskan bahwa pembiasaan yang dilakukan oleh anak, juga diperlukan penguatan berupa pengulangan-pengulangan (Soekamto \& Winaputra, 1997, h. 37).

Metode bernyanyi sangat efektif dalam menghafalkan lagu-lagu bacaan doa, nama malaikat, nama huruf, nama angka, dan lain sebagainya. Pada aspek kognitif dan sosial anak, metode ini berperan aktif dalam mengasah memori anak, melatih emosi sosional anak dan akhirnya akan membuat anak semakin nyaman dengan dunia prasekolah dengan berbagai aktivitas di dalamnya (Ndari dkk., 2018, h. 137).

Metode keteladanan yang lebih menekankan pada penampilan langsung atau aktualisasi sikap-sikap positif kepada anak (Fakhruddin, 2019, h. 378), sehingga sosok guru perlu mencontohkan dengan sebaik mungkin kepada anak. Selain itu, guru merupakan sosok ideal bagi anak. Segala tingkah laku, bicara, dan lainnya tidak lepas dari penglihatan anak. Anak akan menjadi berontak dalam dirinya jika guru menyuruh sesuatu yang positif tetapi aktualnya guru malah berbuat apa yang tidak sesuai dengan apa yang disampaikan. Selain itu, menurut Bandura, seorang anak belajar berdasarkan proses peniruan (imitation) dan konsep percontohan (modelling) (Suryono \& Haryanto, 2012, h. 88).

Metode nasihat yang menggunakan pesan-pesan positif kepada anak dan pesan-pesan tersebut disampaikan dengan kelembutan dan kebahagiaan (Fakhruddin, 2019, h. 378). Konsep menasehati pada anak usia dini bukan dengan cara bentakan atau cacian tetapi pada penjelasan yang melembutkan kepada anak. Metode nasihat yang diterapkan di RA Ar-Rahmah berupa pengingatan dan nasihat yang lembut kepada anak ketika setiap pagi ada kegiatan salam-salaman kepada guru sebelum memasuki kelas, anak-anak yang masih suka berkelahi dengan temantemannya, suka menjaili temannya, dan bullying kepada temannya.

Dalam pemberian materi hafalan surat-surat pendek dan pembelajaran tentang pendidikan agama Islam dilakukan secara bergiliran. Ketika dikumpulkan dalam satu sekolah di halaman sekolah, guru menginstruksikan anak-anak untuk berbasis dan diawali dengan berdoa bersama, mengucapkan secara bersama-sama tentang peraturan di RA Ar-Rahmah, kemudian dilanjutkan mengucapkan Pancasila, bernyanyi-nyayi supaya semangat, baris berbaris, jalan di tempat, diselingi bernyayi tentang nama-nama hari, bulan dan nama malaikat. Kemudian anak-anak diberikan pertanyaan-pertanyaan yang diajukan oleh guru. Pertanyaan tersebut berupa tugas dari malaikat ataupun sebaliknya. Jika anak bisa menjawab dengan benar, maka anak boleh mengambil peralatan salat di tas masing-masing, dan jika yang salah dalam menjawab pertanyaan yang diajukan guru maka anak harus mundur ke belakang barisan dan menunggu giliran untuk menjawab kembali. Selingan antara nyanyian, hafalan doa-doa, gerakan baris berbaris dan sampai pada pertanyaan yang diajukan guru bukan lain untuk mengurangi kejenuhan anak pada materi belajar yang ada (Fadhilah dkk., 2014, h. 13). 
Media dalam belajar dan bermain juga terbilang ampuh dalam pengenalan angka dan huruf seperti media puzzle (Irawan, 2019, h. 37). Sehingga tidak salah setiap TK ataupun RA memiliki permainan puzzle termasuk RA Ar-Rahmah. Media bermain lainnya adalah dengan permainan bola dalam mengasah perkembangan kognitif dan sensori motorik halus pada anak (Karoma, 2019, h. 60). Selain itu, pengasahan aspek motorik kasar pada anak bisa dengan media bermain simpai dan hulahoop (Zahroh dkk., 2019, h. 30). Media permainan yang bisa digunakan dalam pengembangan sosial pada anak dengan media bermain dadu (Hewi \& Surpida, 2019, h. 115). RA Ar-Rahmah terbilang cukup lengkap dengan wahana permainan yang dapat mengasah aspek motorik kasar dan motorik halusnya, selain itu media bermain lainnya dalam pengembangan kognitif dan sosial pada anak yang ada di dalam kelas.

\section{Kemampuan Ideal Anak}

Pada anak usia 4-6 tahun rata-rata anak memiliki kebutuhan untuk bergerak lebih aktif seiring dengan perkembangan kognitifnya (pola pikir) yang memudahkan untuk merencanakan dan memikirkan konsekuensi dari tindakannya. Aspek kognitif pada anak merupakan sesuatu yang unik dan kadang-kadang "ajaib" karena para orang dewasa tidak mampu menebak dan menduga "isi pikiran" anak. Jean Piaget memberikan panduan berupa perkembangan kognitif anak berdasarkan tahap perkembangannya. Menurut Piaget anak usia dini yang berada di Taman kanakkanak (TK) masih berada tahapan praoperasional yang memiliki karakter sebagai berikut:

1. Ditandai dengan perkembangan bahasa yang lebih rapi dan tertata sehingga anak mampu berkomunikasi secara verbal dengan lebih lancar dibandingkan pada tahapan usia sebelumnya.

2. Mampu melakukan permainan yang sifatnya simbolis seperti bermain pura-pura sebagai dokter, guru, polisi, dan lain-lain.

3. Anak-anak sudah mampu memikirkan pengaruh dari tindakannya sendiri.

4. Anak mampu meniru tindakan lingkungan sekitarnya.

5. Pola pikir anak cenderung egosentris (terkadang masih menuruti sudut pandangnya sendiri, belum optimal berpikir berdasarkan sudut pandang orang lain) dan centralized (terpusat) pada satu titik pusat.

6. Anak cenderung belum dapat memahami fakta yang dibalik atau belum mampu berpikir abstrak (Purna \& Kinasih, 2017, h. 19-20).

Milestone memberikan penjelasan yang lebih kompleks tentang perkembangan kognitif anak. Pada usia 4-6 tahun anak sudah mampu membuat puisi, menamai dan mengenali lebih banyak warna dibandingkan anak usia sebelumnya, menggambar orang dengan bentuk yang sederhana, menghitung sampai 10, sudah mengerti alamat rumahnya, dan mampu memberi judul dan menceritakan tentang gambar yang dibuatnya (Purna \& Kinasih, 2017, h. 21). Selain itu memainkan peran sebagai orang lain atau sesuatu yang lain dapat mengembangkan kognitif pada anak (Anggraini \& Putri, 2019, h. 104)

Menurut Krech \&Crutchfield, perilaku sosial pada anak akan tampak pada pola respon antar orang yang dinyatakan dengan hubungan timbal balik antar individu (Ibrahim, 2001, hlm. 23). Aspek sosial anak sangat berkaitan dengan proses seseorang untuk menanggapi kejadian tertentu dan mengekspresikannya melalui wajah, gerakan tubuh, dan kata-kata. Cara anak merespon peristiwa, kejadian, perlakuan tertentu dari lingkungannya bergantung pada keterampilan sosial dan keterampilan anak dalam memecahkan masalah yang dihadapinya. Erickson berpendapat bahwa anak pada usia 5-6 tahun, tahap psikososial anak pada tahap stadium genital lokomotorik yang sangat dipengaruhi oleh situasi lingkungan keluarga dan lingkungan sekitar yang sehat termasuk sekolah. Pada tahapan ini terjadi pertikaian komponen di dalam diri anak yaitu antara inisiatif dan rasa bersalah (Purna \& Kinasih, 2017, h. 30).

Hal yang menarik pada teori Erickson mengenai perilaku positif (perilaku prososial) pada anak yaitu rasa empati anak pada lingkungannya. Empati merupakan kemampuan seseorang untuk ikut merasakan perasaan orang lain atau melihat dari sudut pandang orang lain. pada anak usia 5- 
6 tahun rata-rata anak dapat diajak berdiskusi dan berdialog tentang perasaan agar mereka mampu memahami perasaan orang lain. Dialog yang dilakukan dengan suasana yang nyaman dan minim kritikan dapat dilakukan sejalan dengan perkembangan bahasa anak, karena pesatnya kata-kata yang sudah dikuasainya. Anak usia tersebut secara umum sudah siap berlatih empati secara lebih luas melalui ekspresi wajah, gerak tubuh, dan kata-kata (Purna \& Kinasih, 2017, h. 33).

Anak-anak yang berada di RA Ar-Rahmah kelompok B1 secara umum sedang menjalani perkembangan fisik yang aktif. Pada anak usia ini juga bisa disebut dengan puncak perkembangan fisik anak. Hal ini bisa ditunjukkan dengan aktifnya fungsi motorik anak seperti tangan, kaki, kepala dan lainnya sehingga terlihat banyak gerakan bahkan terkadang membuat repot guru. Pada anak usia 5-6 tahun, anak sudah mencapai keseimbangan tubuhnya, pandai berjalan dan berlari, naik-turun tangga, meloncat dari tanah dengan kedua kakinya secara bersamaan, dan beberapa anak sudah bisa bersepeda. Untuk memfasilitasinya, sangat penting mengembangan potensi motorik anak dengan belajar yang aktif dan bersifat learning by doing (belajar sambil melakukan) (Purna \& Kinasih, 2017, h. 17-18).

Sarana dan prasarana bermain bagi anak juga diperlukan sekolah untuk menunjang gerak motoriknya yang ingin selalu mencoba permainan dan alat baru yang ada di sekolah. Sehingga anak bisa memilih permainan apa yang dia kehendaki, dan lebih bervariasi. Dari perkembangan kognitif, sosial dan motorik anak tersebut, guru perlu tahu mengenai perkemangan anak usia 5-6 tahun secara idealnya anak pada usia tersebut. Sehingga permasalahan-permasalahan yang ada di TK/RA tidak serta merta kesalahan dari anak, tapi bisa saja beberapa anak mengalami keterlambatan atau percepatan dalam perkembangannya. Sehingga guru dapat dicarikan solusi yang terbaik dengan menggunakan pendekatan yang lebih humanis kepada anak.

\section{SIMPULAN DAN SARAN}

Optimalisasi perkembangan kognitif, sosial dan motorik anak merupakan tugas dari seorang guru di sekolah. Guru perlu mengerti perkembangan ideal seorang anak dilihat dari aspek kognitif, sosial dan motoriknya. RA Ar-Rahmah kelompok B1 memiliki karakter dan perkembangan yang berbeda-beda, ada yang pintar dalam berhitung, aktif dalam bergerak dan bermain, aktif dalam menjawab, responsif pada guru dan teman, dan lainnya. Pembelajaran yang dilakukan guru pada anak kelompok B1 lebih bervariatif dalam menggunakan metode belajarnya seperti bernyanyi, pembiasaan, keteladanan, nasihat, dan lainnya sesuai dengan materi apa yang hendak diajarkan kepada anak. Selingan antara satu materi dengan materi pembelajaran yang lainnya juga penting dalam pembelajaran yang dilakukan di RA Ar-Rahmah. Program-program unggulan yang dimiliki RA Ar-Rahmah juga mendorong guru untuk berpikir bersama agar tujuan yang dikehendaki sekolah tercapai. Keterlambatan perkembangan pada anak memang salah satu hambatan dalam mengoptimalkan perkembangan anak.

Untuk guru yang mengajar anak-anak yang masih berumur 4-6 tahun haruslah mengerti perkembangan tiap peserta didik. Karena pada usia tersebut merupakan usia yang masuk pada masa golden age, peran lingkungan di sekitar sangatlah menentukan termasuk guru dan teman sebaya di sekolah, orang tua di rumah dan teman bermain di lingkungan rumah. Tiap anak juga memiliki potensinya masing-masing baik dari ranah kognitif, sosial maupun motorik anak. Maka dari itu, Perlunya kerjasama yang baik antara guru di sekolah dan orang tua di rumah dalam mengoptimalkan perkembangan kognitif, sosial dan motorik anak.

\section{DAFTAR RUJUKAN}

Anggraini, W., \& Putri, A. D. (2019). Penerapan Metode Bermain Peran (Role Playing) dalam Mengembangkan Kognitif Anak Usia 5-6 Tahun. JECED : Journal of Early Childhood Education, 1(2), 104-114. https://doi.org/10.15642/jeced.v1i2.466 
Astuti, M. (2013). Implementasi Program Fullday School Sebagai Usaha Mendorong Perkembangan Sosial Peserta Didik TK Unggulan Al-Ya'lu Kota Malang. Jurnal Kebijakan dan Pengembangan Pendidikan, 1(2), 133-140. https://doi.org/10.22219/jkpp.v1i2.1561

Darmadi. (2018). ABORSI PENDIDIKAN: "Memotret Reputasi dan Ambivalensi Pendidikan Indonesia." Surakarta: CV Kekata Group.

Desmita. (2010). Psikologi Perkembangan Peserta Didik. Bandung: PT Rosda Karya.

Dewi, K. R., Gading, I. K., \& Magta, M. (2019). Pengaruh Pendekatan Pembelajaran Eksplorasi Lingkungan Sekitar terhadap Kemampuan Sains Anak Taman Kanak-kanak. Jurnal Pendidikan Anak Usia Dini Undiksha, 7(3), 215-225. http://dx.doi.org/10.23887/paud.v7i2.18997

Dwiyogo, W. D. (2018). Pembelajaran Berbasis Blended Learning. Depok: PT Raja Grafindo Persada.

Fadhilah, M., Filasofa, L. M. K., \& Wantini. (2014). Edutainment Pendidikan Anak Usia Dini. Jakarta: Kencana Prenadamedia Group.

Fakhruddin, A. U. (2019). Menjadi Guru PAUD. Jakarta: PT Elex Media Komputindo Kompas Gramedia.

Hewi, L., \& Surpida. (2019). Permainan Dadu pada Pengembangan Perilaku Prososial Anak di RA An-Nur Kota Kendari. JECED : Journal of Early Childhood Education, 1(2), 115-128. https://doi.org/10.15642/jeced.v1i2.468

Hurlock, E. B. (2014). Psikologi Perkembangan. Jakarta: PT Raja Grafindo Persada.

Ibrahim, R. (2001). Pembinaan Perilaku Sosial Melalui Pendidikan Jasmani. Jakarta: Departemen Pendidikan Nasional.

Irawan, A. I. (2019). Peningkatan Kemampuan Mengenal Lambang Bilangan 1-10 Melalui Penggunaan Media Buah Puzzle Angka Pada Kelompok A Di Raudlatul Athfal Babussalam, Krian, Sidoarjo. JECED: Journal of Early Childhood Education, 1(1), 37-49. https://doi.org/10.15642/jeced.v1i1.503

Iswantiningtyas, V., \& Raharjo, I. B. (2016). Kemandirian Anak Usia Dini ( Studi di Taman Kanak-kanak Tauladan Kecamatan Pare Kabupaten Kediri ). SELING: Jurnal Program Studi PGRA, 2(1), 59-62. https://doi.org/10.29062/seling.v2i1.217

Karoma, S. (2019). Peningkatan Kemampuan Mengenal Lima Huruf Vokal Melalui Media Bola Huruf Pada Anak Usia 3-4 Tahun. JECED : Journal of Early Childhood Education, 1(1), 60-66. https://doi.org/10.15642/jeced.v1i1.501

Khoiruzzadi, M., \& Fajriyah, N. (2019). Pembelajaran Toilet Training dalam Melatih Kemandirian Anak. JECED: Journal of Early Childhood Education, 1(2), 142-154. https://doi.org/10.15642/jeced.v1i2.481

Krombholz, H. (2006). Physical Performance in Relation to Age, Sex, Birth Order, Social Class, and Sports Activities of Preschool Children. SAGE Journals, 102(2), 477-484. https://doi.org/10.2466\%2Fpms.102.2.477-484

Li, X., \& Atkins, M. S. (2004). Early Childhood Computer Experience and Cognitive and Motor Development. Pediatrics, 113(6), 1715-1722. https://doi.org/10.1542/peds.113.6.1715

Mulandini, N. W., Tirtayani, L. A., \& Manuaba, I. B. S. (2019). Pengaruh Metode Proyek Berbasis Pendekatan Saintifik terhadap Kemampuan Motorik Halus Anak Kelompok B di TK Gugus III Kecamatan Tampaksiring Tahun Pelajaran 2018/2019. Jurnal Pendidikan Anak Usia Dini Undiksha, 7(1), 36-46. http://dx.doi.org/10.23887/paud.v7i1.18743

Muslih, A., \& Rahimah. (2018). Analisis Kebijakan PAUD Mengungkap Isu-Isu Menarik Seputar PAUD. Wonosobo: Penerbit Mangku Bumi.

Ndari, S. S., Viayastri, A., \& Masykuroh, K. (2018). Metode Perkembangan Sosial Emosi Anak Usia Dini. Tasikmalaya: EDU Publisher. 
Noll, R. B., Robert A., Z., Fitzgerald, H. E., \& Curtis, W. J. (1992). Cognitive and motoric functioning of sons of alcoholic fathers and controls: The early childhood years. Journal TOC: Developmental Psychology, 28(4), 665-675. https://psycnet.apa.org/doi/10.1037/0012-1649.28.4.665

Nurmalitasari, F. (2015). Perkembangan Sosial Emosi pada Anak Usia Prasekolah. Buletin Psikologi, 23(2), 103-111. https://doi.org/10.22146/bpsi.10567

Piek, J. P., Bradbury, G. S., Elsley, S. C., \& Tate, L. (2008). Motor Coordination and SocialEmotional Behaviour in Preschool-aged Children. ournal International Journal of Disability, Development and Education, 55(2), 143-151. https://doi.org/10.1080/10349120802033592

Purna, R. S., \& Kinasih, A. S. (2017). Psikologi Pendidikan Anak Usia Dini Menumbuhkembangkan Potensi "Bintang" Anak di TK Atraktif. Jakarta: PT Indeks Permata Puri Media.

Putri, A. A. A. D. (2019). Penerapan Metode Bercerita Menggunakan Media Audio-Visual untuk Meningkatkan Pemahaman Anak Usia Dini Mengenai Bencana Alam. Jurnal Pendidikan Anak Usia Dini Undiksha, 7(3), 246-250. http://dx.doi.org/10.23887/paud.v7i3.23233

Silranti, M., \& Yaswinda. (2019). Pengembangan Kemandirian Anak Usia 5-6 Tahun di TK Dharmawanita Tunas Harapan. Jurnal Caksana: Pendidikan Anak Usia Dini, 2(1), 39-48. https://doi.org/10.31326/jcpaud.v2i1.367

Soekamto, T., \& Winaputra, U. S. (1997). Teori Belajar Dan Model-Model Pembelajaran. Jakarta: Dikti.

Suciasih, N. N. L., Mahadewi, L. P. P., \& Antara, P. A. (2019). Pengaruh Pembelajaran DLPS terhadap Kemampuan Sains Permulaan Kelompok A di Gugus VIII Kecamatan Buleleng. Jurnal Pendidikan Anak Usia Dini Undiksha, 7(3), 226-235. http://dx.doi.org/10.23887/paud.v7i2.19000

Suryono, \& Haryanto. (2012). Belajar Dan Pembelajaran Teori Dan Konsep Dasar. Bandung: Remaja Rosdakarya.

Untariana, A. F., Samawi, A., \& Wulandari, R. T. (2019). Tingkat Pengetahuan Guru PAUD tentang Pembelajaran Seni Tari Anak Usia Dini. Jurnal Pendidikan Anak Usia Dini Undiksha, 7(3), 246-254. http://dx.doi.org/10.23887/paud.v7i3.17237

Venetsanou, F., \& Kambas, A. (2010). Environmental Factors Affecting Preschoolers' Motor Development. Early Childhood Education Journal, 37(1), 319-327. https://doi.org/10.1007/s10643-009-0350-z

Yus, A. (2015). Penilaian Perkembangan Belajar Anak Taman Kanak-kanak. Jakarta: Kencana. Zahroh, A., Aziz, Y., \& Dwijo, A. Q. N. E. S. (2019). Peningkatan Keterampilan Motorik Kasar Melalui Alat Permainan Simpai pada Anak Kelompok A di Taman Kanak-Kanak Dharma Wanita Bangun Ungging Mojokerto. JECED : Journal of Early Childhood Education, 1(1), 30-36. https://doi.org/10.15642/jeced.v1i1.493

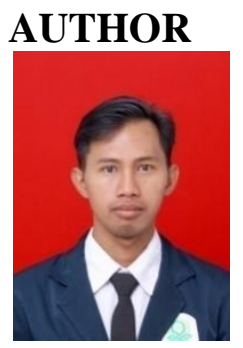

Muhammad Khoiruzzadi berasal dari Pekalongan dan sekarang masih aktif sebagai mahasiswa magister semester akhirProgram Studi Interdisciplinary Islamic Studies Konsentrasi Psikologi Pendidikan Islam di Pascasarjana UIN Sunan Kalijaga Yogyakarta. Email: khoiruzzadie@gmail.com. CP: 085640935302

Mabid Barokah berasal dari Pontianak dan sekarang masih aktif sebagai mahasiswa magister semester akhirProgram Studi Interdisciplinary Islamic Studies Konsentrasi Psikologi Pendidikan 
Islam di Pascasarjana UIN Sunan Kalijaga Yogyakarta. Email: mabidbarokah26@gmail.com. CP: 089674771568

Aisiyatin Kamila berasal dari Situbondo dan sekarang masih aktif sebagai mahasiswa magister semester akhirProgram Studi Interdisciplinary Islamic Studies Konsentrasi Psikologi Pendidikan Islam di Pascasarjana UIN Sunan Kalijaga Yogyakarta. Email: mielaairandah@ gmail.com. CP: 085222063020 